\title{
1. The external dimensions of EU migration and asylum policies in times of crisis
}

\author{
Sergio Carrera, Juan Santos Vara and Tineke \\ Strik
}

\section{INTRODUCTION: CRISIS, RULE OF LAW AND LEGITIMACY}

This edited volume has been conceived in the framework of the Jean Monnet Chair in EU External Action at the University of Salamanca awarded to Professor Juan Santos Vara in 2016 (574677-EPP-1-2016-1-ES-EPPJMO -CHAIR). It is based on further reflection and discussion on the works presented at the workshop on 'The External Dimensions of EU Migration Policies: Effectiveness, Fairness and Rule of Law Reconsidered', held in Salamanca on the 19 and 20 October 2017 in cooperation with the Centre of European Policy Studies (CEPS). It also benefited from the support of the Office of the Eighth Centenary of the University of Salamanca.

The emergence of the European refugee humanitarian crisis in 2015 brought once more to the spotlight the foundations of EU cooperation in the domains of migration management and asylum. The increase in the number of entries by asylum seekers provoked a political and legitimation crisis in the Union. A crisis which, despite having its deepest roots in the incapacity or lack of political willingness by many EU Member States to secure solidarity-based responses and safe reception conditions for those seeking international protection, hit back at the EU and its added value in these policy domains as a whole. The fact that political crises are often utilised, instrumentalised and even co-created by political and security actors to pursue their own interests and agendas has not passed unnoticed by the literature. 'Crisis labelling' has constituted a recurrent practice by policy makers. It has not only enabled 'new patterns of action', but also justified the continuation of 'established 
or old ones' which are by and large controversial. ${ }^{1}$ This book studies EU migration and asylum policies in times of crisis by assessing old and new patterns of cooperation in EU migration management policies in the scope of third-country cooperation, which has often been called EU external migration law and policy.

The concept of crisis is inherently contested. There is no clear or widely accepted notion in the discipline of international relations. ${ }^{2}$ Crisis remains an unresolved notion. ${ }^{3}$ Recent scholarly contributions have signalled the importance of studying exceptional or crisis-led practices within liberal democratic polities from the perspective of highly relational and heavily mediated socio-political practices of relevant trans-governmental actors. ${ }^{4}$ They have underlined the need for scholarship to critically engage with these notions so as not to fall into reproducing and co-producing a 'crisis process' that normalises a conception of political authority and decision making and, by doing so, marginalising the importance of democratic political practices and legitimation struggles. ${ }^{5}$ Nabers has suggested to focus on crisis as an essential qualitative feature of 'the social' and 'the political', instead of an understanding of crisis as 'crisis decision making' or 'crisis management'. He has called for an examination of how allegedly 'objective crises' are in fact expressions or 'meaning structures' in particular configurations of historically contingent social forms of power, and how they are related to structural and discursive changes. ${ }^{6}$

Crisis is certainly not a new feature in EU migration policy making. Crisis politics have played a key role in the making of a policy area where Member States' governments have shown persistent reluctance in transferring legal competences towards EU institutional instances. The EU therefore presents

J. Jeandesboz and P. Pallister-Wilkins, 'Crisis, enforcement and control at the EU borders' in A. Lindley (ed.), Crisis and Migration: Critical Perspectives (Routledge 2014) 115-35.

2 For a historical exploration of the notion of crisis and its use as a metaphor in politics, economics and history from the seventeenth century, R. Koselleck and M. Richter, 'Crisis' (2006) $67 \mathrm{~J}$ of the History of Ideas 357-400. For a more recent discussion refer to W. Merkel, 'Is there a crisis of democracy? Can we answer the question?' (2013) 1 Democratic Theory 11-25; W. Merkel, 'Democracies and their crises reconsidered' (2016) 3 Democratic Theory 91-108.

3 D. Nabers, A Poststructuralist Discourse: Theory of Global Politics (Palgrave Macmillan 2015). The classical definition of 'crisis' delivered by Hermann in 1969 is very often quoted: C. Hermann, Crisis in Foreign Policy: A Simulation Analysis (Bobbs Merrill 1969).

4 J. Huysmans, 'The jargon of exception - On Schmitt, Agamben and the absence of political society' (2008) 2 International Political Sociology 165-83.

5 Ibid. See also D. Bigo, Exception et ban : à propos de l' «état d'exception » (2009) Erytheis, 2.

6 Nabers (n 3). 
its own distinctive socio-political and legal specificities at times of studying 'crisis labelling' and the outputs of 'crisis policy making'. European integration has developed its own understandings and supranational legal configurations of 'who does what' and 'who is competent to do what', and under which rule of law, democracy and fundamental rights guarantees, checks and balances as well as safeguards. The study of these relations and struggles from an EU perspective needs to take account of the normative or constitutional framework which has been enshrined in the EU Treaties, the Charter of Fundamental Rights of the European Union (CFR), EU secondary legislation and the jurisprudence of the Court of Justice of the European Union (CJEU). This framework offers the structural parameters within which one can understand the scope and implications of new and old patterns of international cooperation on migration management. The entry into force of the Lisbon Treaty since December 2009 marked a fundamental milestone in European cooperation on migration and asylum policies.

A goal behind the Lisbon treaty-making process was to strengthen the EU's legitimacy in these policies by ensuring more robust democratic accountability, judicial control and human rights protections. Mirroring national constitutional frameworks, and their founding principles such as the one on the separation of powers, the Lisbon Treaty gave boost to the principle of interinstitutional balance in the EU Area of Freedom, Security and Justice (AFSJ). It consolidated the role of the European Parliament (EP) as co-legislator in the adoption of new laws and the conclusion of international agreements, and placed it as co-owner of the EU migration policy agenda. ${ }^{7}$ The CJEU became also fully competent to interpret and review any adopted EU legal acts and agreements in these areas. In a move away from the 'intergovernmentalism' and 'nationalism', ${ }^{8}$ which used to reign in European cooperation in Justice and Home Affairs (JHA), the implementation of the Lisbon Treaty constitutional mandate has also meant the recognition that migration policies are now not only under shared legal competence between EU Member States and the EU; in some specific migration-related domains the EU now counts with exclusive competence to legislate. This means that the rules and procedures laid down in the EU Treaties are the guide to follow in any subsequent policy development

7 S. Carrera, 'The impact of the Treaty of Lisbon over EU Policies on migration, asylum and borders: the struggles over the ownership of the Stockholm programme' in E. Guild, P. Minderhoud and R. Cholewinski (eds), The First Decade of EU Migration and Asylum Law (Martinus Nijhoff Publishers 2012) 229-54.

8 S. Carrera, E. Guild, and T. Balzacq, 'The changing dynamics of security in an enlarged European Union' in S. Carrera, D. Bigo, E. Guild, and R. Walker, Europe's 21st Century Challenge: Delivering Liberty (Ashgate 2010) 31-48. 
and international cooperation on matters related to migration, asylum and borders.

Human rights have been said to ground an inherently legitimate rule of law. As Habermas puts it, despite their limitations, 'human rights function at the same time as sensors for exclusionary practices exercised in their name'. ${ }^{9}$ Within the EU legal system, human rights have acquired their own specific substantial, material and institutional features in the shapes of general principles. The CFR has been said to constitute the 'bill of rights' pertinent to the EU. It makes the Union's legal system autonomous and hierarchical from the perspective of the principle of supremacy of EU law. ${ }^{10}$ The CFR applies both to the policies and actions of the European institutions and Member States within the scope of application of EU law. Importantly, a major innovation by the Lisbon Treaty was the conversion of the EU Charter into a legally binding instrument with the same value as the Treaties. Many of the CFR's provisions do cover and directly apply to EU Member States' actions on migration management. A key passage in the EU Charter is the one dealing with justice, where fair trial and effective remedies rights in cases of alleged human rights violations have been formally proclaimed as central ingredients in the effective delivery of the rest of fundamental rights. The observance of fundamental rights standards as well as the norms of international law provide here a 'natural' check on any sovereign authority, ${ }^{11}$ including when powers go supranational in EU actors and their venues of cooperation.

By putting democratic control, judicial scrutiny and fundamental rights at the heart of EU policies on migration and asylum, the most far-reaching contribution stemming from the 'Lisbonisation' of the AFSJ was the 'constitutionalisation' of European cooperation in domains with such huge repercussions for the liberty and security of individuals. Equally central, it also meant anchoring its very foundations on the protection and full compliance by both EU Member States and European institutions of a core set of legal principles enshrined in Article 2 of the Treaty on European Union (TEU). These chiefly relate to safeguarding the rule of law, democracy and fundamental rights. Mutual trust and confidence among all the actors and institutions involved, and between those and European citizens and residents, lays on the EU to firmly stand for effective protection of these principles.

\section{Ibid., 120.}

10 S. Peers, T. Hervey, J. Kenner, and A. Ward, The EU Charter of Fundamental Rights (Hart Publishing 2014).

11 R. Dworkin, 'A new philosophy of international law' (2013) 41 Philosophy and Public Affairs 2-30. 
Previous scholarly contributions have alluded to a triangular relationship between the rule of law, democracy and fundamental rights. ${ }^{12}$ These three notions are co-constitutive or connatural, and in relation in a triangular interaction which ensures 'democratic rule of law with fundamental rights', i.e. the legally based rule of a democratic state that delivers fundamental rights. The three criteria have been said to be indivisibly interconnected and interdependent. The Commission has provided an 'EU definition' of the rule of law in its 2014 Communication titled 'A New EU Framework to Strengthen the Rule of Law'. ${ }^{13}$ Accordingly, the Communication underlines that while the precise content of the principles and standards stemming from the rule of law may vary at national level, there are certain principles which lie at the core of the meaning of the rule of law as a 'common value' in accordance with Article 2 TEU. These include:

[the principle of] legality, which implies a transparent, accountable, democratic and pluralistic process for enacting laws; legal certainty; prohibition of arbitrariness of the executive powers; independent and impartial courts; effective judicial review including respect for fundamental rights; and equality before the law. ${ }^{14}$

The Commission recognised in this same Communication that:

respect for the rule of law is intrinsically linked to respect for democracy and for fundamental rights: there can be no democracy and respect for fundamental rights without respect for the rule of law and vice versa. Fundamental rights are effective only if they are justiciable. Democracy is protected if the fundamental role of the judiciary, including constitutional courts, can ensure freedom of expression, freedom of assembly and respect of the rules governing the political and electoral process. ${ }^{15}$

This definition draws direct inspiration from those previously provided by the Council of Europe's Venice Commission. ${ }^{16}$

12 S. Carrera, E. Guild, and N. Hernanz, 'The Triangular relationship between fundamental rights, democracy and the rule of law in the EU: towards an EU Copenhagen Mechanism' (CEPS 2013) (the original study done for the Directorate General for Internal Policies of the EP, PE 493.031).

13 Commission, 'A new EU framework to strengthen the rule of law' (Communication) COM (2014) 158 final.

14 Ibid., 4.

15 Ibid.

16 Refer to the European Commission of Democracy through Law (Venice Commission), 'Rule of Law Checklist' (CDL-AD(2016)007, Study No. 711/2013, 18 March 2016). 
A core tenet inherent to the notion of the rule of law is the principle of separation of powers. This principle has received a long-standing consideration and reflection as an essential element of rule of law and constitutionalism across the scholarly literature. ${ }^{17}$ The notion requires and presupposes an equilibrium between gubernaculum - the day-to-day law making and application of the law by the sovereign - and jurisdictio - the checks on the law, which lie beyond the sovereign's reach. ${ }^{18}$ The principle of separation of powers finds a strong relative in the principles of interinstitutional balances as well as effective judicial protection. As soon as 1983 the European Court of Justice held in Les Verts that the EU is 'based on the rule of law inasmuch as neither its Member States nor its institutions can avoid a review of the question whether the measures adopted by them are in conformity with the basic Constitutional Charter, the Treaty'. ${ }^{19}$ In subsequent rulings the CJEU has made clear that the operational separation of powers implies an independent and effective judicial review. ${ }^{20}$

The Lisbon Treaty includes an express acknowledgement of the importance of effective judicial protection by EU Member States in Article 19(1) TEU, which stipulates that 'Member States shall provide remedies sufficient to ensure effective legal protection in the fields covered by Union law'. The Court recently highlighted the importance of judicial independence in the EU legal system in the case Associação Sindical dos Juizes Portugueses of 28 February 2018. ${ }^{21}$ In this ruling, the Court provided the first interpretation of Article 47 of the CFR, and specifically recognised the existence of a general principle of EU law on effective judicial protection. The CJEU held that:

The principle of the effective judicial protection of individuals' rights under EU law, referred to in the second subparagraph of Article 19(1) TEU, is a general principle of EU law stemming from the constitutional traditions common to the Member States, which has been enshrined in Articles 6 and 13 of the European Convention

\footnotetext{
17 J.E. Finn, Constitutions in Crisis: Political Violence and the Rule of Law (OUP 1991).

18 P. Bárd, S. Carrera, E. Guild, and D. Kochenov, 'An EU mechanism of democracy, the rule of law and fundamental rights' (2016) CEPS Papers in Liberty and Security in Europe; G. Palombella, 'The rule of law as an institutional ideal' in L. Morlino and G. Palombella (eds), Rule of Law and Democracy: Inquiries into Internal and External Issues (Brill 2010) 3-37; G. Palombella, 'The rule of law and its core' in G. Palombella and N. Walker (eds), Relocating the Rule of Law (Hart Publishing 2009) $17-42$.

19 Case 294/83, Les Verts $v$ European Parliament, ECLI:EU:C:1986:166, para. 23.

20 Case C-279/09, DEB v Germany, ECLI:EU:C:2010:811, para. 58.

21 Case C-64/16, Associação Sindical dos Juizes Portugueses v Tribunal de Contas, ECLI:EU:C:2018:117. The case dealt with the legality of a reduction in the remuneration of public officials and judges in Portugal due to its interference with the principle of judicial independence.
} 
for the Protection of Human Rights and Fundamental Freedoms, signed in Rome on 4 November 1950, and which is now reaffirmed by Article 47 of the Charter. ${ }^{22}$

The ruling highlights that 'the very existence of effective judicial review designed to ensure compliance with EU law is of the essence of the rule of law'.23

These principles and foundations of European cooperation are primarily aimed and destined to support and guarantee the legitimacy of EU policies. The notion of legitimacy - and what makes political authority rightful or legitimate - has been widely covered and discussed by political theory and philosophy. Suffice here to say that the degree of legitimacy of a particular political order has been said to explain the depth of support that a particular government can call on. Another branch of the literature has covered questions of legitimacy for liberal democracies which find themselves under political stress or legitimation crises. ${ }^{24}$ More recently the literature has wondered whether when speaking of EU legitimacy we should use the same criteria as those determining the legitimacy of its Member States' governments. ${ }^{25}$ This book, and the collection of essays comprising it, examines the ways in which 'the politics of migration crisis' and their patterns of cooperation and legal/ policy outcomes evidenced since 2015 affect and might even undermine the EU's legitimacy in these policy areas.

\section{THE EUROPEAN REFUGEE HUMANITARIAN CRISIS: NEW AND OLD WAYS OF EU COOPERATION}

If anything, the so-called European refugee humanitarian crisis has provided us with new evidence when studying 'crisis labelling' and the opportunities that it gives to national and trans-governmental actors to pursue old and new ways of 'doing things' on migration policies. Crisis usually calls for urgent and exceptional actions; the inherent risk is that speed and urgency often disregard and take over the rule of law checks and balances which are seen by

\section{Ibid., para. 35 .}

Ibid., para. 36 .

J. Habermas, Legitimation Crisis (Beacon Press 1975); C. Offe, 'The Welfare State and the Future of Socialism' in J. Keane (ed.), Contradictions of the Welfare State (Hutchinson 1984) 252-99. On the governance challenges of European democracies see also J.M. Crozier, S. Huntington, and J. Watanuki, The Crisis of Democracy: Report on the Governmentality of Democracies to the Trilateral Commission (New York University Press 1975).

25 D. Beetham and C. Lord, Legitimacy and the EU (Routledge 2013). 
security actors and professionals as obstacles to pursuing their own interests and control-oriented security agendas. Has this new 'crisis labelling' allowed for the continuation and at times reinvigoration of previously existing logics of EU cooperation focused on security, i.e. external border controls and the expulsion (return and readmission) of irregular immigrants and asylum seekers from the Union? And what do these crisis-led patterns of cooperation actually mean for the EU: do they lead to more or less European integration, or even disintegration in the migration policy domain?

Previous scholarship has discussed how the progressive development of an EU immigration policy has heavily relied on the idea to strengthen third-country cooperation in areas of returns and readmission, and the proliferation of mechanisms of externalisation ${ }^{26}$ or extraterritorial migration control. ${ }^{27}$ Unsurprisingly, third-country cooperation was once more presented by the Commission's 2015 European Agenda on Migration as one of the key political priorities to respond to this 'new crisis'. The external dimensions of EU migration policy have a longer history, however. During the last decades the EU has developed a complex and diversified matrix of policy, legal and financial instruments delineating cooperation with third countries in the management of migration, borders and asylum in the so-called Global Approach to Migration and Mobility (GAMM). These include, for instance, readmission agreements, visa facilitation agreements, mobility partnerships and common agendas on migration and mobility, high level dialogues, consultative processes, joint declarations and several financial frameworks. ${ }^{28}$

The literature has, however, struggled to make rational sense of this evolving and dynamic matrix of instruments and new modes of governance when the EU

26 S. Lavenex, 'Shifting up and out: the foreign policy of European immigration control' (2006) 29 West European Politics 329-50; S. Lavenex, 'The external governance of EU internal security' (2008) $31 \mathrm{~J}$ of European Integration 83-102; S. Lavenex, 'Multilevelling EU external governance: the role of international organizations in the diffusion of EU migration policies' (2016) $42 \mathrm{~J}$ of Ethnic and Migration Studies 554-70; S. Lavenex, D. Lehmkuhl, and N. Wichmann, 'Modes of external governance: a cross-national and cross-sectoral comparison' (2009) 16 J of European Public Policy 813-33; S. Carrera, L. den Hertog, and J. Parkin, 'EU migration policy in the wake of the Arab Spring: what prospects for EU-Southern Mediterranean relations?' (2012) 15 MEDPRO Technical Report 1.

27 B. Ryan and V. Mitsilegas (eds), Extraterritorial Immigration Control: Legal Challenges (Martinus Nijhoff Publishers 2010).

28 S. Carrera, N. Reslow, and R. Radescu, EU External Migration Policies: A Preliminary Mapping of the Instruments, the Actors and their Priorities (Report for FP7 Project EURA-NET, 2015) (Transnational Migration in Transition); K. Eisele, The External Dimension of the EU's Migration Policy: Different Legal Positions of Third Country Nationals in the EU: A Comparative Perspective (Martinus Nijhoff Publishers 2014). 
goes abroad on migration policies. ${ }^{29}$ The encounters between the migration and foreign policy may trigger tensions between the EU institutions and Member States in the control over the external dimension of migration policy. ${ }^{30}$ Within the literature on decision making dynamics, a debate can be identified between authors who claim that the Member States are dominant, in particular through the role of officials. ${ }^{31}$ Others point at the actual significant influence of the Commission using its expert authority, though internal competition leads to destabilizing turf-wars. ${ }^{32}$ Authors attributing power to the EU institutions however recognise the limited role of the EP. ${ }^{33}$ Research frameworks have also frequently used the policy transfer and implementation theories, ${ }^{34}$ or have applied the concept of instrumentation in an attempt to gain a better understanding of EU policy in this complex and enlarging field. ${ }^{35}$ Political science has devoted attention to factors of convergence, diffusion, venue-shopping, including escape from anti-immigrant sentiment, ${ }^{36}$ conditionality and issue linkage. ${ }^{37}$ More recent contributions have added that EU external migration policy and legal instruments can be understood as intersecting policy universes or new venues of cooperation, interactions and interest-shaping where differ-

29 For a typology refer to Carrera, Reslow, and Radescu (n 28). Also see Lavenex, Lehmkuhl and Wichmann (n 26).

30 N. Reslow, 'The politics of EU external migration policy' in A. Weinar, S. Bonjour and L. Zhyznomirska (eds), The Routledge Handbook of the Politics of Migration in Europe (Routledge 2018) 391-400.

31 S. Lavenex and R. Kunz, 'The migration-development nexus in EU external relations' (2008) 30 J of European Integration 439-57; M.H. Chou, 'The European security agenda and the 'External Dimension' of EU asylum and migration cooperation' (2009) 10 Perspectives on European Politics and Society 541-59.

32 C. Boswell, 'Evasion, reinterpretation and decoupling: European Commission responses to the 'External Dimension' of immigration and asylum' (2008) 31 West European Politics 491-512; D. Wunderlich, 'Differentiation and policy convergence against long odds: lessons from implementing EU migration policy in Morocco' (2010) 15 Mediterranean Politics 249-72.

33 Lavenex and Kunz (n 31).

34 E. Hafner-Burton and M.A. Pollack, 'Mainstreaming International governance: the environment, gender, and IO performance in the European Union' (2010) 5 Rev of International Organization 285-313.

35 F. Trauner and S. Wolff, 'The negotiation and contestation of EU migration policy instruments: a research framework' (2014) 16 EJML 1-18.

36 Boswell (n 32).

37 F. Jurje and S. Lavenex, 'Trade agreements as venues for 'Market Power Europe'? The case of immigration policy' (2014) 52 JCMS 320-36; L. Martin, 'Credibility, costs, and institutions: cooperation on economic sanctions' (1993) 45 World Politics 406-32; J. Hollifield, 'Trade, migration and development: the risks and rewards of openness' (IZA Institute of Labor Economics Seminar, Bonn, Germany, 11 March 2008). 
ent communities of policy makers and professionals of security interrelate to each other and find allies sharing their interests in the processes of policy formulation and implementation. ${ }^{38}$

This literature analysing the internal EU processes (the internal dimension) merely develops separately from literature examining the dynamics between the EU actors and non-EU countries (the external dimension). ${ }^{39}$ Finding explanations to the way the interactions function, however, requires that the roles and preferences of the EU institutions, Member States and non-EU countries are all taken into account. ${ }^{40}$ This entire policy system comprising these three sets of actors, has been conceptualised as a three-level game, based on the concept of two-level games as developed by Putnam in $1988 .{ }^{41}$ The three-level game concept facilitates the analysis and explanation of how different preferences lead to certain positions or outcomes. The policy conditionality model is identified as a strong driver for certain behaviour by non-EU countries, based on a cost-benefit calculation. ${ }^{42}$ Other authors, however, have found that the dependency of the EU and its Member States to cooperation by non-EU countries results in a 'reversed conditionality'. ${ }^{43}$

This book moves beyond the state of the art by studying the ways in which developments of the external dimensions of EU migration policy since the European refugee humanitarian crisis raise any novel issues and challenges in light of EU rule of law and fundamental rights standards laid down in the Lisbon Treaty. While acknowledging that from a historical perspective there is often little new under the sun in political practices and imaginations, the various chapter contributions in this book identify and examine old and new patterns of cooperation in the ways various EU and Member States' actors delineate and frame their cooperation with third countries regarding migration

38 S. Carrera, L. den Hertog, D. Kostakopoulou, and M. Panizzon, The External Faces of EU Migration, Borders and Asylum Policies: Intersecting Policy Universes (Brill/Nijhoff 2018).

39 Reslow (n 30) 391-400.

40 M.H. Chou and M. Gilbert, 'The EU-Senegal Mobility Partnership: from launch to suspension and negotiation failure' (2012) 8 JCER 409-27; S. Lavenex and R. Stucky, "Partnering" for Migration in EU external relations' in R. Kunz, S. Lavenex and M. Panizzon (eds), Multilayered Migration Governance: The Promise of Partnership (Routledge 2011) 116-41; Wunderlich (n 32).

${ }^{41}$ N. Reslow and M. Vink, 'Three-level games in EU external migration policy: negotiating mobility partnerships in West Africa' (2015) 53 JCMS 857-74.

42 F. Schimmelfennig and U. Sedelmeier, 'Governance by conditionality: EU rule transfer to the candidate countries of Central and Eastern Europe' (2004) $11 \mathrm{~J}$ of European Public Policy 661-79.

43 J.P. Casserino, 'Informalising readmission agreements in the European Neighbourhood' (2007) 42 The Intl Spectator 179-99. 
management and security. The literature has already explored and signalled the incremental use of 'variable geometry', differentiation or flexibility in EU cooperation on JHA, some of which are expressly allowed by the EU Treaties themselves. ${ }^{44}$

The case studies explored in this volume reveal, however, something else: there has been a clear tendency and strategy to move away from or go outside the decision making rules and institutional principles enshrined in the Lisbon Treaty to advance third-country cooperation on migration management. There are sound indicia since 2015 of an expansionist or incremental move towards the use of extra-Treaty cooperation and instruments in this domain which pose major EU constitutional challenges. Are we witnessing a trend of 'de-constitutionalising' EU migration and asylum policies? This book examines how these new facets of EU external migration policies do not help in advancing European integration, but rather the opposite, bringing a tangible risk of 'disintegrating' areas of intervention where the EU already counts with exclusive or at least shared legal competence. As more intergovernmental elements are brought in, the institutional interests and effectiveness, but also its checks and balances, may be trampled underfoot by (diverging) national interests. The use of national competences by Member States to the benefit of their own preferences may hinder or even run counter to the common goals and especially threaten the aimed comprehensiveness of the EU external dimension of migration policy. The first victim of this disintegration will most probably be the fundamental rights which the EU needs to comply with while going abroad.

These new instruments have included statements, deals, compacts, joint ways forward, joint declarations etc. Concrete examples illustrating the implementation of this novel approach include the so-called EU-Turkey Statement or EU readmission arrangements. They fall outside the EU Treaties and constitute policy tools which stand far away from the ordinary shapes of, and checks and balances applicable to, international agreements in the EU legal system. They escape EU rule of law checks and balances and stand at odds with various EU general principles. Specially, the policy choice to go extra-Treaties means side-lining the EP and thus democratic accountability, but also the judicial control by the CJEU in Luxembourg. That notwithstanding, the implementation of these instruments presents very visible and often profound effects for the rights and freedoms of asylum seekers and irregular immigrants.

Some of these policy developments, and their compatibility with the EU Treaties and the rule of law, are reaching national and European courts, includ-

44 B. de Witte, A. Ott and E. Vos (eds), Between Flexibility and Disintegration: The Trajectory of Differentiation in EU Law (Edward Elgar 2017). 
ing the CJEU. One of the main issues which is being subject to judicial adjudication is not only their actual legal nature and effects, but also more generally the ways in which outputs of 'EU crisis-led policy making' can be captured by EU Treaty and legal standards on democratic rule of law scrutiny, fundamental rights compliance and financial accountability. As the case of the EU-Turkey Statement shows, irrespective of their actual legal nature, accountability is increasingly focused on who is implementing them in practice at times of ascertaining who is to be responsible for their potential negative effects including fundamental rights violations - on the ground. A key challenge is the extent to which these new facets of the external dimensions of migration policy in the EU contribute or jeopardise rule of law-complying and legitimate migration policies.

\section{STRUCTURE OF THE BOOK AND CONTRIBUTIONS}

The book is divided into two main parts, which will be briefly described here. Part I of the book (EU External Migration Policies: New and Old Dynamics) explores new and old dynamics characterising the external dimensions of EU external migration policies and law. It pays particular attention to the most relevant policy developments which originated or were reinforced since the emergence of the so-called European refugee humanitarian crisis since 2015. The various chapter contributions assess the extent to which there has been any noticeable policy change and continuity in the setting of priorities, driving principles and in the use of legal and policy tools and instruments by the EU and its Member States in the policy responses to the crisis. These are put in light of the division of competences between the EU and its Member States, as well as the democratic rule of law and fundamental rights standards laid down in the Lisbon Treaty and the CFR.

Santos Vara analyses the implications of using alternative instruments to international agreements to manage migration cooperation with third countries for the EU institutional framework. Even though the tendency to use soft law instruments in EU external relations is not new, the implementation of informal arrangements and memoranda of understanding in the field of migration might have serious implications for asylum seekers and irregular migrants. There is also a widespread understanding that the EU is more likely to succeed in managing migration cooperation with third countries with informal migration arrangements than with international agreements. However, the signing of non-binding agreements on migration does not necessarily lead in practice to a more efficient cooperation on migration and, in particular, to an increase in the number of returns of irregular migrants. Santos Vara argues that this consideration challenges the policy assumptions behind the informalisation of 
EU migration cooperation with third countries, in particular the proliferation of informal arrangements in the EU readmission policy.

To what extent do the EU Treaties grant competence to the EU for external cooperation on migration, and more specifically, for delegating its border control activities to third countries? García Andrade makes a distinction between national competences and EU competences and shows the problem issues arising in case of mixed agreements. While analysing the role of mixity in the field of migration, she assesses the reasons for the use of mixed agreements: is it mandatory or facultative, and what are the legal consequences? She concludes that mixed agreements that are mandatory because the Union lacks certain external competences such as conditions of admission of legal migrants, can be a useful tool for the cooperation with third countries. If, however, the Union is to exercise its exclusive external competence, as is the case with regard to association agreements, involvement of the competence of Member States on migration may lead to drawbacks, for instance due to the need for unanimous ratification of Member States. According to García Andrade, in case of concurrent competences like with readmission agreements, insisting on a mixed agreement by Member States could even infringe the principle of sincere cooperation as it may jeopardise the achievement of the objectives assigned to it by the Treaties.

Strik examines to what extent the EU's externalised asylum and migration policy contributes to the objective of the Global Compact on Refugees to achieve 'a more equitable sharing of the burden and responsibility for hosting and supporting the world's refugees'. She shows how the EU is working towards outsourcing its responsibility for refugees by on the one hand amending its internal standards on the safe third-country concept, and on the other hand the formal and informal agreements with third countries. According to Strik, the consequences of readmission agreements, bilateral border cooperation as well as the prioritisation of preventing irregular migration in its foreign policies, undermine the GAMM objective of enhancing the protection for refugees. The EU-Turkey Statement was the first test case of applying the safe third-country concept, requiring a high and sustainable level of protection. As this Statement is often perceived as a blueprint for cooperation models with North African countries, Strik assesses the potential consequences of this type of cooperation with Tunisia and Egypt. She argues that this shifting out policy not only enhances the risk of weakening the rights of refugees, but also reduces their mobility chances by impeding regional free movement arrangements. As the EU policy towards third countries encourages them to adopt this shifting out policy, the responsibility for refugees ultimately lies with fewer rather than more countries.

In line with Strik, González Vega analyses the safe country concepts in the EU asylum acquis, which he defines as 'disconnection procedures'. He 
describes how these concepts have developed and expanded from the use by one single country to the incorporation into the Common European Asylum System (CEAS) and extended to different types of safe third countries as well as the 'internal flight concept' by the adoption of the Aznar Protocol. After having pointed at the growing importance of these concepts through the use of readmission agreements, González Vega explores the consistency of those developments with the telos of the Geneva Convention - namely the non-refoulement principle - and its coherence with the judicial limits related to the expulsion of aliens set out by European courts. While the author considers the application of the safe third-country concept in the implementation of the EU-Turkey Statement as a threat to the non-refoulement principle, he expects a serious breach of the obligations under the Geneva Convention in case of expansion to North African countries. By comparing the European Court of Human Rights' (ECtHR) responses to bilateral cooperation and recent CJEU's decisions on Dublin Regulation and the Visa Code, he foresees that the implications of the Refugee Convention for the interpretation of the EU's externalised asylum and migration policies will lack judicial review.

Reslow contributes to the fledgling academic literature on the crisis by examining the effect of the refugee crisis in 2015 on the content and form of EU external migration policy. Her analyses of the policy responses by the European Agenda on Migration, the Valletta Summit, the EU-Turkey Statement and the Migration Partnership Framework lead her to conclude that in comparison to previous policy, the two years after 2015 show a significant degree of policy stability with a lack of major policy innovations. According to Reslow this means that the long-standing criticisms of the human rights implications are not addressed. Instead, due to the turn to informal cooperation models, these concerns may grow in absence of a role for the EP. Like other authors in this book, Reslow problematises the low level of democratic scrutiny and accountability and hence, the limited legitimacy. In order to understand this political stability, Reslow suggests to draw explaining factors from theories on policy change and policy stability. This could form a basis for a research agenda for empirical tests, with the aim to support recommendations on policy transformation.

Fahey views the increasing number of soft law tools in EU external migration policy, characterised by flexibility and the deployment of management lexicon, as a means to avoid or minimalise the need for 'hard' binding law. Fahey characterises the external dimension of migration policy as hyper-legislation, referring to the high quantity of diverse instruments which attribute legal effect, combined with de-legislation, meaning the exclusion of judicial review and legal redress by the CJEU. According to the author, this contradiction exemplifies the EU's AFSJ, of which distinct internal and external facets may be viewed as innately contradictory and judicial review 
increasingly excluded. However, she also relates this multiplicity of constitutional competences applied in external migration to other crisis-ridden subjects of EU law like the financial crisis. In her view, these responses to crises reveal the problematic nature of EU law making, providing reason for concern about basic conceptualisations of the rule of law therein.

Part II of the book (EU Crisis-led Patterns of Cooperation in Light of EU Rule of Law) provides a detailed examination of EU policy actors and new instruments which have been developed in response to the recent European refugee humanitarian crisis. A cross-cutting approach lying behind Part II is the implications and effects of the involvement of these actors and the adoption of extra-Treaty instruments and patterns of cooperation in light of EU rule of law and fundamental rights principles and standards. It explores the new shapes driving EU cooperation with third countries on readmission. Special focus is given to EU-Turkey cooperation on migration and the 2016 EU-Turkey Statement, as well as the use of specific non-legally binding policy and financial tools such as the compacts, mobility partnerships, EU readmission arrangements and EU development funding tools. The chapters also focus on the proliferation of extraterritorial migration control mechanisms driven by the increasing involvement of military actors, such as the so-called European Union Naval Force Mediterranean (EUNAVFOR Med) Operation Sophia in migration management in the Mediterranean.

Eisele concentrates on the institutional aspects of EU readmission agreements, which has become one of the standard tools to tackle irregular migration to the EU during the last 15 years. While taking stock of the EU's readmission policy, Eisele shows that this instrument has been criticised throughout the years, especially those involving transit countries, for its human rights implications and lack of effectiveness. At the same time she shares the observation of other authors in this book of a trend towards informalisation. These informal agreements and arrangements imply that the Union is not exercising its legal competences. Eisele problematises that this informalisation therefore deprives the EP of its competence to exercise democratic control over the EU's external action, which means a loss of transparency, democratic scrutiny and accountability. Similarly, readmission arrangements fall outside the scope of the CJEU, in contrast to formal readmission agreements. As a consequence of the institutional balance being at stake, this trend enables Member States to deviate from the EU's principles. In her concluding remark, Eisele points at the risk that the judgment on the EU-Turkey Statement may further encourage Member States to circumvent the EU's system of remedies and checks and balances.

Carrera, den Hertog and Stefan examine whether the EU-Turkey Statement has provided for legality, safety and effectiveness in the framework of EU migration and asylum law. It is submitted that the Statement amounts to reversing 'Lisbonisation', most notably by posing profound rule of law and 
fundamental rights challenges and re-injecting intergovernmentalism. This argument is based on the circumvention of democratic and judicial scrutiny by means of the informal Statement, but also on the legal and practical effects of the deal. The authors come to the conclusion that the return mechanism and the asylum procedures following from the implementation of the Statement, particularly the assumption that Turkey is a safe third country, cannot stand the lawfulness test. In this context they also point at the deterioration of reception and detention conditions in Greece. While applying the EU effectiveness principle including the requirement of lawfulness, the authors find that the Statement fails to pass the effectiveness test, as it does not meet the objectives stipulated by EU law and stands at odds with the principles of loyal and sincere cooperation and good administration, the latter because of the omission to undertake an impact assessment of the human rights consequences. In addition, the Statement has weakened the EU's ability to address the worsening rule of law situation in Turkey, since it has turned itself into a dependency on the country.

Gatti and Ott dive into the distribution of competences between the EU and the Member States in informal agreements, the EU-Turkey Statement. They analyse the legal nature of this Statement in the light of the decision of the General Court (GC) to declined jurisdiction in an annulment procedure by refugees affected by the Statement. The authors investigate different institutional options: first, the Statement as an (binding or non-binding) instrument entered into by the Member States; second, as a non-binding arrangement entered into by the Union; and third, as a binding agreement concluded by the Union. They observe a tension between the shared competences of the Union regarding the migration and asylum commitments covered by the Statement, and the exclusive competence acquired by the Union to conclude a readmission agreement with Turkey. The authors argue in favour of as well as against the Statement having binding effect, but also point at the invalidity of the potentially binding agreement, as the treaty-making procedure has not been complied with. They conclude that in any event the Statement was authored by the EU - and not by the Member States, as the GC found in the joined cases $N F, N G$ and $N M$. They criticise that with such cooperation models, the EU favours pragmatism over concerns for human rights, democracy and the rule of law, as it limits the individual changes of legal redress. These legal uncertainties are even more concerning as the EU-Turkey Statement serves as a source of inspiration in the context of the EU's external migration policy.

Groenendijk has made a comparison between three main models of cooperation with Turkey, with a special focus on their legal basis and legal consequences of cooperation on migration between the EU and a third country. The European Economic Community (EEC), later the EU and its Member States over time have concluded agreements with Turkey concerning elements 
of migration policy: the Association Agreement in 1963 with its subsequent Protocol and Association Council Decisions, the readmission agreement in 2013 and the EU-Turkey Statement of 2016. In a comparative analysis, Groenendijk elaborates on the aim, the form and the legal character of these agreements, the rights of individual migrants and the extent to which the parties complied with the agreements. His rather surprising conclusion is that the level of implementation does not depend on the level of bindingness. The two formal agreements did not guarantee actual enforcement by both parties, whereas the informal EU-Turkey Statement, with less electoral cost, had real effects on the policy and behaviour of the states involved. According to Groenendijk, the financial incentives constitute the main causes for living up to the arrangements. At the same time, however, promises by Member States to open up legal migration channels have hardly been implemented.

Through a case study on the EU-Jordan Compact, Panizzon compared the second wave of externalised EU asylum and migration policy, based on the new Partnership Framework, to its first wave, which applied the principles of the GAMM. With this second wave, 'opening legal pathways' shifted into a narrative of 'keeping migrants in the region'. This aim, fuelled by internal disagreement on solidarity, led the EU to increase its leverage and revive conditionality towards first-safe-countries hosting large refugee populations. According to Panizzon, however, conditionality inherently conflicts with the universality of human rights protection. Panizzon uncovers several macro-level conflicts of the EU-Jordan Compact with World Trade Organization (WTO) law, such as the preferential version of a 'trade-for-development' overturning the vision of a level-playing field promoted among the EU neighbourhood and under WTO law, as it is only applied to 'particularly affected' EU neighbours. Acknowledging the need to create sustainable prospects for Syrian refugees and to offer the Jordan government appropriate compensation, Panizzon formulates a number of recommendations for the EU's policy. One of them is to shift to trade-in-services by inserting a minimum employment quota of Syrian refugees for EU (humanitarian) service providers in Jordan under a prospective Deep and Comprehensive Free Trade Area or in Jordan's public procurement.

Tittel-Mosser has analysed the EU cooperation with two other African countries through mobility partnerships: Morocco and Cape Verde. In line with Adam and Trauner, Tittel-Mosser sheds light on the agency of the third countries. The author examines whether the EU and the Member States unilaterally use mobility partnerships to support the externalisation of EU migration policy or whether third countries play a more active role in these developments. She found a significant difference between the two countries. The high dependence of Cape Verde on the EU made the country sign the readmission agreement and enabled the EU to influence the implementation of the mobility partnerships at each step of the process. Morocco on the other 
hand uses its strong negotiation position, following from its borders with the EU territory. Morocco's development of a new migration and asylum policy merely stemmed from its own interest in becoming a key player in the African region. Although mobility partnerships are not binding, they still have legal and policy relevance for migration and asylum policy in third countries. In that way, the EU manages to a certain extent to achieve its aim to externalise the reception of migrants and refugees to third countries.

Adam and Trauner shed light on the EU external cooperation with a country on another continent. In their chapter they take the perspective and agency of Ghana, a West African migrant-sending country, by analysing its response to the EU approach. Building on expert interviews and fieldwork in Accra, they argue that the EU has achieved several migration-related objectives vis-à-vis Ghana including tighter and more regulation, enhanced border control capacities and a stronger awareness of the migration issue. However, Ghana keeps its sovereignty and agency by being selective in its response. It did not refuse the support and money that the EU offered, but it remained reluctant to cooperate in readmission, which is a priority for the EU. The research confirms previous conclusions that power asymmetries and EU conditionalities do not automatically lead to cooperative behaviour. The prioritisation of migration makes the EU vulnerable and simultaneously empowers African states, as it enlarges their leverage. Furthermore the authors emphasise that external influence does not come all of a sudden, but concerns a long-term process that needs to be institutionalised.

In their contributions, Gomez Arana and McArdle, as well as Mitsilegas focus on the security orientation of the EU externalised asylum and migration policy. Gomez Arana and McArdle argue that the security-based approach, which they find in the EU's migration policies since the 1990s, impedes the development of a comprehensive migration policy, and has failed to address the human issues arising from crises such as in the Mediterranean. This security concept being so central in the EU policy, has fuelled the rhetoric of 'fortress Europe', portraying Europe as a region that needs to be protected against external threats like migration. According to the authors, this remains constant during the development of the GAMM, and has been reinforced by the response to the crisis in 2015. They point out that EUNAVFOR Med was the first crisis management operation intersecting the internal and external approaches to EU security. This security-driven approach in the Mediterranean is even more problematic in the absence of effective responsibility and accountability mechanisms. Gomez Arana and McArdle conclude that with this recently enhanced security focus, the EU has missed the opportunity to live up to its statements to create a 'comprehensive approach'. In order to be effective, they recommend the EU to withdraw from the Eurocentric and defensive approach and to develop a real integrated policy. 
Mitsilegas, who shares the view of the previous authors that the security-based approach has grown, concludes that this has led to the proliferation of mechanisms of extraterritorial immigration control. Mitsilegas offers a typology of mechanisms of extraterritorial immigration control and maps their evolution in the context of the fight against human smuggling, which is increasingly perceived as a primary security threat. While analysing the immigration control by means of the activities of the European Border and Coast Guard Agency (FRONTEX), he identifies two distinct processes: on the one hand the privatisation of extraterritorial border control through the criminalisation of assisting irregular migration on humanitarian grounds, and on the other hand, the militarisation of border control through actions like Operation Sophia. Mitsilegas argues that the multilevel border control measures and their interconnections result in or even aim at preventing justice and thus undermine the rule of law. He urges for the need to address the challenges to the rule of law ex ante (due to the measures lacking transparency and democratic control) and ex post (due to the lack of human rights standards and human rights accountability). Similar to the view of González Vega, he is pessimistic about the chance that the CJEU will scrutinise the extraterritorial border control practices and address these violations of the rule of law. Instead, however, he claims that the ECtHR would find that extraterritorial surveillance transmitted by state parties to third countries, resulting in human rights violations of migrants, would fall under its jurisdiction through the effective control criterion. Mitsilegas calls for the need to find judicial answers to the question of compatibility of the preventive justice paradigm of extraterritorial immigration control with human rights and the rule of law. 